\title{
Minocycline Block Copolymer Micelles and their Anti-Inflammatory Effects on Microglia ${ }^{a}$
}

\author{
Ghareb Mohamed Soliman, Angela O. Choi, Dusica Maysinger, \\ Françoise M. Winnik*
}

$\mathrm{MH}$, a semisynthetic tetracycline antibiotic with promising neuroprotective properties, was encapsulated into PIC micelles of CMD-PEG as a potential new formulation of $\mathrm{MH}$ for the treatment of neuroinflammatory diseases. PIC micelles were prepared by mixing solutions of a $\mathrm{Ca}^{2+} / \mathrm{MH}$ chelate and CMD-PEG copolymer in a Tris-HCl buffer. Light scattering and ${ }^{1} \mathrm{H}$ NMR studies confirmed that $\mathrm{Ca}^{2+} / \mathrm{MH} / \mathrm{CMD}-\mathrm{PEG}$ core-corona micelles form at charge neutrality having a hydrodynamic radius $\approx 100 \mathrm{~nm}$ and incorporating $\approx 50 \mathrm{wt} . \% \mathrm{MH}$. $\mathrm{MH}$ entrapment in the micelles core sustained its release for up to $24 \mathrm{~h}$ under physiological conditions. The micelles protected the drug against degradation in aqueous solutions at room temperature and at $37^{\circ} \mathrm{C}$ in the presence of FBS. The micelles were stable in aqueous solution for up to one month, after freeze drying and in the presence of FBS and BSA. CMD-PEG copolymers did not induce cytotoxicity in human hepatocytes and murine microglia (N9) in concentrations as high as $15 \mathrm{mg} \cdot \mathrm{mL}^{-1}$ after incubation for $24 \mathrm{~h}$. MH micelles were able to reduce the inflammation in murine microglia (N9) activated by LPS. These results strongly suggest that MH PIC micelles can be useful in the treatment of neuroinflammatory disorders.

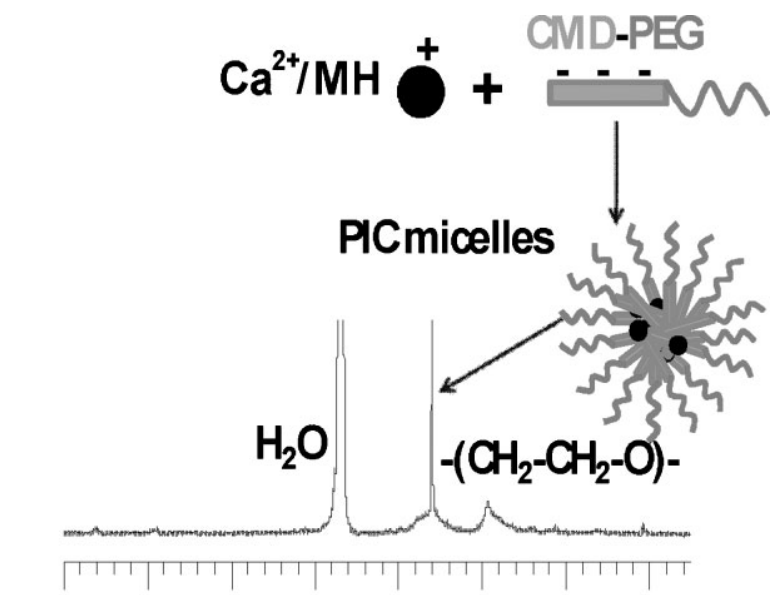

PPM $\begin{array}{lllllll}7.0 & 6.0 & 5.0 & 4.0 & 3.0 & 2.0 & 1.0\end{array}$
G. M. Soliman, F. M. Winnik

Faculty of Pharmacy and Department of Chemistry, Universite de Montréal, CP 6128 Succursale Centre Ville, Montréal, $\mathrm{O} C, \mathrm{H}_{3} \mathrm{C} 3 \mathrm{~J} 7$, Canada

Fax: (1) 514340 3245; E-mail: francoise.winnik@umontreal.ca A. O. Choi, D. Maysinger

Department of Pharmacology and Therapeutics, McGill University, 3655 Promenade Sir-William-Osler, Room 1314, McIntyre Medical Sciences Building, Montreal, $\mathrm{O} C, \mathrm{H}_{3} \mathrm{C}$ 1Y6, Canada

${ }^{a} \square$ Supporting information for this article is available at the bottom of the article's abstract page, which can be accessed from the journal's homepage at http://www.mbs-journal.de, or from the author.

\section{Introduction}

There is increasing evidence from studies in cell cultures, in animal models, and clinical trials that some antibiotics might have beneficial anti-inflammatory effects in the central nervous system. ${ }^{[1,2]}$ For example, the tetracycline antibiotic minocycline exerts antioxidant and anti-inflammatory effects in hyperactivated microglia in animal models of stroke, inhibiting their activation and proliferation. ${ }^{[1,3-5]}$ Microglia comprise approximately $12 \%$ of cells in the brain and predominate in the gray matter. ${ }^{[6]}$ They typically exist in their surveillance state characterized by a ramified morphology and monitor the brain environment. 
Microglia are readily activated by a variety of stimuli, including pathogens producing pro-inflammatory cytokines and particulate matter (e.g. axonal debris). The microglial protective and destructive roles depend on the degree of their activation and therefore agents which can modulate the activation process are clinically useful to shift the balance in favor of microglial protective state. ${ }^{[7]}$ Minocycline seems to be one such agent which has been explored as a monotherapy or in drug combinations. However, its poor stability and the numerous side effects related to the large doses required present serious limitations in terms of clinical applications.

Minocycline is routinely administered orally for the treatment of infectious and inflammatory diseases, such as acne vulgaris, rheumatoid arthritis, and some sexually transmitted diseases, in doses on the order of $3 \mathrm{mg} \mathrm{kg}^{-1} \mathrm{~d}^{-1}$. ${ }^{[8]}$ It was shown to induce neurorestoration in various animal models when applied intraperitoneally in doses of up to $200 \mathrm{mg} \mathrm{kg}^{-1}$ several times a day. ${ }^{[9,10]}$

Oral formulations for the treatment of bacterial infections contain minocycline hydrochloride ( $\mathrm{MH}$, Figure 1 ), which is an ionic compound very soluble in water. ${ }^{[1,12]} \mathrm{MH}$ is well absorbed when administered orally. However, due to its numerous side effects it is recommended to administer it intravenously (IV). ${ }^{[10]}$ It was noted, however, that after IV administration of $\mathrm{MH}$, the levels of the drug in the brain were significantly lower than its concentration in the plasma, possibly as a consequence of the short MH lifetime in the bloodstream. ${ }^{[10]} \mathrm{MH}$ is notoriously unstable in aqueous solution, especially in acidic or alkaline media where it undergoes epimerization at $C_{4} \cdot{ }^{[1,13,14]}$ The resulting epi-MH is much less potent than $\mathrm{MH}$ and is prone to further degradation upon exposure to oxidants or to light. ${ }^{[15]}$

The poor stability of $\mathrm{MH}$ in biological environment and serious side effects require a new approach for its administration in clinics. Thus, several research groups have developed and evaluated new means of $\mathrm{MH}$ delivery. For instance, Hu et al. have demonstrated that MH entrapped within PEGylated liposomes [PEG=poly(ethylene glycol)] retained its activity and the effectiveness of IV injection of MH PEGylated liposomes every five days was comparable to that of daily intraperitoneal injection of $\mathrm{MH}$ alone. ${ }^{[16]}$ Core-shell nanoparticles with an inner core serving as nanocontainer for the drug and a shell providing both colloidal stability in aqueous media and stealth properties in the bloodstream were also assessed as delivery vehicles for $\mathrm{MH}$. Thus, Liang et al. have prepared a micellar formulation of $\mathrm{MH}$ by entrapping it into octadecyl quaternized carboxymethyl chitosan nanoparticles. ${ }^{[17]}$ The MH-loaded nanoparticles were $\approx 290 \mathrm{~nm}$ in size and contained up to $22 \mathrm{wt}$. $\% \mathrm{MH}$. In vitro studies indicated that the drug could be released from the particles, but no further data on the effectiveness of the formulation were presented so far. Another promising approach consists in converting minocycline into alkanoyl-10-O-minocycline, a hydrophobic derivative of minocycline known to retain the antioxidant, anti-inflammatory, and antibiotic activities of minocycline. In aqueous media, alkanoyl-10-O-minocyclines self-assemble into nanoparticles expected to partition favorably in the blood-brain barrier and to possess enhanced stability, compared to minocycline. ${ }^{[9]}$ The encouraging results reported on the use of nanoparticles for the IV administration of $\mathrm{MH}$ prompted us to assess formulations of $\mathrm{MH}$ using polyion complex (PIC) micelles which also belong to the class of core-shell nanoparticles. ${ }^{[18-20]}$ The solid core of PIC micelles contains an ionic drug neutralized by the ionic segment of an oppositely-charged hydrophilic diblock copolymer. ${ }^{[19,21]}$ The shell of PIC micelles is formed by the second segment of the diblock copolymer, usually a PEG chain selected in view of its hydrophilic, non toxic properties and its outstanding stealth characteristics in vivo. ${ }^{[2,23]}$ PIC micelles have found clinical applications in cancer chemotherapy and in gene delivery. ${ }^{[24-26]}$ The usefulness of PIC micelles in drug delivery derives from their small size ( $\approx 100 \mathrm{~nm}$ ), high drug loading, ease of fabrication and handling, thermodynamic stability, and design flexibility.

Since $\mathrm{MH}$ is an amphoteric molecule with an isoelectric point of 6.4 , it does not interact strongly with polyelectrolytes under physiological conditions. ${ }^{[11]}$ Consequently, $\mathrm{MH}$ is not suitable, per se, for incorporation into PIC micelles. It is important to recall here that, like all tetracycline antibiotics, $\mathrm{MH}$ is a metal-binding antibacterial agent, known to form complexes with divalent or trivalent cations by chelation of the $C_{11}-C_{12}-C_{1}$ carbonyl functionalities. ${ }^{[27-29]}$ Depending on the metal salt to drug relative concentrations, $\mathrm{MH}$ can form 1:1 or 2:1 metal iondrug chelates with calcium or magnesium ions. The 1:1 chelated form of $\mathrm{MH}$ is neutral under physiological conditions ( $\mathrm{pH} 7.4)$, whereas the 2:1 metal ion/MH chelate is cationic, since the $\mathrm{pK}_{\mathrm{a}} \mathrm{s}$ of $\mathrm{MH}$ are 5 and 9.5 for the $C_{7}$ and $C_{4}$ amino groups, respectively. ${ }^{[30]}$ This cationic form of $\mathrm{MH}$ should be able to undergo electrostatic interactions with polyanions and form PIC micelles with an appropriate

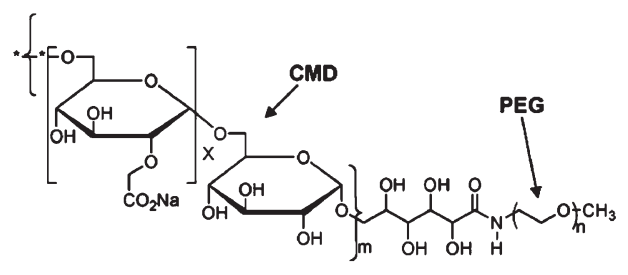


hydrophilic anionic diblock copolymer. To test this hypothesis, we selected carboxymethyldextran-blockpoly(ethylene glycol) (CMD-PEG, Figure 1), a diblock copolymer that consists of a neutral PEG block linked to an anionic CMD block in which approximately $85 \%$ of the glucose units bear carboxylate groups. ${ }^{[31]}$ This copolymer is known to be non-toxic and to form PIC micelles, 30-50 nm in radius, with cationic water soluble drugs, such as diminazene diaceturate, presenting high drug loading, sustained drug release and excellent stability. ${ }^{[32]}$

The objectives of the studies reported here were to prepare CMD-PEG based PIC micelles loaded with the 2:1 $\mathrm{Ca}^{2+} / \mathrm{MH}$ chelate and to assess their anti-inflammatory activity in activated microglia cells. ${ }^{1} \mathrm{H}$ NMR spectroscopy was used to detect the formation of core-shell micelles in mixed solutions of CMD-PEG and 2:1 $\mathrm{Ca}^{2+} / \mathrm{MH}$. The size of the micelles and their stability under various conditions were assessed by dynamic light scattering (DLS) measurements. Since $\mathrm{MH}$ in aqueous media is prone to rapid degradation, we assessed the stability upon storage in ambient conditions and at $37^{\circ} \mathrm{C}$ of $\mathrm{MH}$ entrapped into PIC micelles. The viability of human hepatocytes and murine microglia (N9) treated with CMD-PEG was assessed using several biochemical assays. The release of the drug from the micelles was determined and nitric oxide release was tested in the presence and absence of ternary $\mathrm{Ca}^{2+} / \mathrm{MH} / \mathrm{CMD}-\mathrm{PEG}$ micelles in N9 microglia cells activated by lipopolysaccharides. The results of this study give strong indications that ternary $\mathrm{Ca}^{2+} / \mathrm{MH} / \mathrm{CMD}-\mathrm{PEG}$ micellar formulations can act as effective delivery systems for $\mathrm{MH}$ to attenuate the excessive microglia activation commonly observed in several neurodegenerative disorders.

\section{Experimental Part}

\section{Materials}

Water was deionized using a Millipore Millio system. $\mathrm{MH}$, trizma ${ }^{\mathbb{R}}$ hydrochloride, amberlite ${ }^{\mathbb{R}}$ IR-120, lipopolysaccharides, bovine serum albumin (BSA), and 3-(4,5-dimethylthiazol-2-yl)2,5-diphenyl tetrazolium bromide (MTT) were purchased from Sigma Aldrich (St. Louis, MO). Dialysis membranes (Spectra/Por, MWCO: 6-8 kDa, unless otherwise indicated) were purchased from Fisher Scientific (Rancho Dominguez, CA). The block copolymer CMD-PEG (Figure 1) was synthesized starting with dextran $\left(M_{\mathrm{n}}=6000 \mathrm{~g} \cdot \mathrm{mol}^{-1}\right)$ and $\alpha$-amino- $\omega$-methoxy-poly(ethylene glycol) $\left(\bar{M}_{\mathrm{n}}=5000 \mathrm{~g} \cdot \mathrm{mol}^{-1}\right)$, as described previously. ${ }^{[31]}$ The degree of carboxymethylation of the dextran block, defined as the number of glucopyranose units having carboxymethyl groups per 100 glucopyranose units, was $85 \%$. The average number of glucopyranosyl and of $-\mathrm{CH}_{2}-\mathrm{CH}_{2}-\mathrm{O}-$ repeat units of the $\mathrm{CMD}$ and PEG segments, were 40 and 140, respectively. Penicillin, streptomycin and Griess Reagent (1\% sulphanilamide, $0.1 \% N$-(1-naphthyl)ethylenediamine dihydrochloride, $5 \%$ phosphoric acid) and fetal bovine serum were purchased from Invitrogen (Carlsbad, CA).
Human hepatocytes and murine microglia (N9) cell lines were from American Type Culture Collection (ATCC). An Alamar Blue (7-hydroxy-3H-phenoxazin-3-one-10-oxide sodium salt) stock solution was purchased from Trek Diagnostic Systems (Cleveland, Ohio).

\section{Preparation of MH-loaded CMD-PEG Micelles}

Stock solutions of $\mathrm{CaCl}_{2}\left(1.27 \mathrm{mg} \cdot \mathrm{mL}^{-1}, 8.63 \cdot 10^{-3} \mathrm{M}\right), \mathrm{MH}$ (2.33 mg.mL ${ }^{-1}, 4.71 \cdot 10^{-3} \mathrm{M}$ ) and CMD-PEG (0.5 mg. $\mathrm{mL}^{-1}, 1.74 \cdot 10^{-3}$. $\mathrm{M}$-COONa) were prepared in Tris- $\mathrm{HCl}$ buffer $\left(10^{-2} \mathrm{M}, \mathrm{pH}\right.$ 7.4). The solution $\mathrm{pH}$ was adjusted to $7.4 \mathrm{using} 0.1 \mathrm{M} \mathrm{NaOH}$ if necessary. Specified volumes of the $\mathrm{CaCl}_{2}$ solution were added to the $\mathrm{MH}$ solution to attain a $\mathrm{Ca}^{2+} /$ ligand molar ratio of 2:1. The $\mathrm{CaCl}_{2} / \mathrm{MH}$ solution was magnetically stirred for $10 \mathrm{~min}$ and added over a 10 -min period to a magnetically stirred CMD-PEG solution, in amounts such that the $[+] /$ $[-]$ ratio ranged from 0.5 to 2.0 , where $[+] /[-]$ is the ratio of the molar concentrations of positive charges provided by the $\mathrm{Ca}^{2+} / \mathrm{drug}$ complex to the negative charges provided by the polymer. In solutions of $\mathrm{pH} 7.4$, the $\mathrm{Ca}^{2+} / \mathrm{MH}$ complex has one positively charged group $\left(\mathrm{C}_{4}\right.$ dimethylammonium, Figure 1 ) while all the carboxylate groups of CMD-PEG are negatively charged (weak polyacid of $\mathrm{p} K_{\mathrm{a}} \approx 4.5$ ). The CMD-PEG concentration was $0.2 \mathrm{mg} \cdot \mathrm{mL}^{-1}$ in all samples. Samples were stirred overnight before measurements.

\section{Characterization}

${ }^{1} \mathrm{H}$ NMR spectra were recorded on a Bruker AV-400 MHz spectrometer operating at $400 \mathrm{MHz}$. Chemical shifts are given relative to external tetramethylsilane (TMS $=0 \mathrm{ppm}$ ). Samples for analysis were prepared by adding aliquots of a $\mathrm{CaCl}_{2}$ solution (20.4 mg. $\mathrm{mL}^{-1}, \mathrm{D}_{2} \mathrm{O}, \mathrm{pH}$ 7.4) to a $\mathrm{MH}$ solution in $\mathrm{D}_{2} \mathrm{O}$ (9.3 mg. $\mathrm{mL}^{-1}, \mathrm{pH} 7.4$ ) such that the $\mathrm{Ca}^{2+} /$ drug molar ratio was 2:1. The resulting solutions were stirred for $10 \mathrm{~min}$. They were added to a stirred solution of CMD-PEG in $\mathrm{D}_{2} \mathrm{O}$ ( $\mathrm{pH}$ 7.4,) in amounts such that the $[+] /[-]$ ratio ranged from $0.25: 1$ to $1.5: 1$. The final polymer concentration was $2.0 \mathrm{mg} \cdot \mathrm{mL}^{-1}$ in all the samples. Control solutions of $\mathrm{MH}, \mathrm{Ca}^{2+} / \mathrm{MH}$, and $\mathrm{MH} / \mathrm{CMD}-\mathrm{PEG}$ in $\mathrm{D}_{2} \mathrm{O}$ were prepared keeping the same concentrations as the metal $\mathrm{Ca}^{2+} /$ $\mathrm{MH} / \mathrm{CMD}$-PEG solutions. All samples were stirred for $1.0 \mathrm{~h}$ before measurements.

DLS measurements were performed on a CGS-3 goniometer (ALV $\mathrm{GmbH}$ ) equipped with an ALV/LSE-5003 multiple- $\tau$ digital correlator (ALV GmbH), a He-Ne laser $(\lambda=632.8 \mathrm{~nm}$ ), and a C25P circulating water bath (Thermo Haake). The scattered light was measured at a scattering angle of $90^{\circ}$. A cumulant analysis was applied to obtain the diffusion coefficient $(D)$ of the micelles and the polydispersity index $\left(P D I=\frac{\mu 2}{\Gamma^{2}}\right.$, where $\mu 2$ is the second order coefficient of the cumulant expansion of the field correlation function and $\bar{\Gamma}$ is the average decay rate). The hydrodynamic radius $\left(R_{\mathrm{H}}\right)$ of the micelles was obtained using the Stokes-Einstein equation. The constrained regularized CONTIN method was used to obtain the particle size distribution. Samples were filtered through a $0.45 \mu \mathrm{m}$ Millex Millipore poly(vinylidene difluoride) (PVDF) membrane prior to measurements. The data presented are the mean of six measurements \pm S.D.

HPLC analysis of MH was performed on an Agilent Technologies HP 1100 chromatography system equipped with a quaternary 
pump, a UV-visible diode array detector, a column thermostat and a HP Vectra computer equipped with the HP-Chemstation software. The assay was carried out at $25^{\circ} \mathrm{C}$ using a $250 \times 4.6 \mathrm{~mm}$ column filled with $5 \mu \mathrm{m}$-reversed phase $\mathrm{C}_{18}$ Hypersil $^{\mathbb{R}}$ BDS (Thermo, Bellefonte, PA) eluted at a flow rate of $1.5 \mathrm{~mL} \cdot \mathrm{min}^{-1}$ with a phosphate buffer $\left(2.5 \times 10^{-2} \mathrm{M}, \mathrm{pH}\right.$ 3.0)-methanol-acetonitrile, $85: 10: 5 \mathrm{v} / \mathrm{v} / \mathrm{v} /$ mixture. $^{[12]}$ The injection volume was $40 \mu \mathrm{L}$ and the run time was $30 \mathrm{~min}$. $\mathrm{MH}$, monitored by its absorbance at $255 \mathrm{~nm}$, had a retention time $\approx 16 \mathrm{~min}$. A calibration curve $\left(r^{2} \geq 0.999\right)$ of $\mathrm{MH}$ was prepared using standard solutions ranging in concentration from 20 to $80 \mu \mathrm{g} \cdot \mathrm{mL}^{-1}$ prepared immediately prior to the assay.

\section{Stability Studies}

To test the stability of MH-micelles in serum, $\mathrm{Ca}^{2+} / \mathrm{MH} / \mathrm{CMD}-\mathrm{PEG}$ micelles (CMD-PEG: $0.2 \mathrm{mg} \cdot \mathrm{mL}^{-1},[+] /[-]=1.0,\left[\mathrm{Ca}^{2+}\right] /[\mathrm{MH}]=2: 1$ ) in Tris-HCl buffer $\left(10^{-2} \mathrm{M}, \mathrm{pH} 7.4\right)$ were prepared as described above. One set of solutions was supplemented with BSA $(0,5,10,20,30$ and $\left.40 \mathrm{mg} \cdot \mathrm{mL}^{-1}\right)$. Another set of samples was supplemented by $5 \%$ fetal bovine serum (FBS). Samples without serum were kept at room temperature for up to $30 \mathrm{~d}$. Serum and BSA-containing solutions were incubated at $37{ }^{\circ} \mathrm{C}$ for $24 \mathrm{~h}$. Samples were analyzed by DLS at various time intervals to determine the $R_{\mathrm{H}}$ and PDI of the micelles.

The chemical stability upon storage of $\mathrm{MH}$ was tested using micelles (CMD-PEG: $0.1 \mathrm{mg} \cdot \mathrm{mL}^{-1},\left[\mathrm{Ca}^{2+}\right] /[\mathrm{MH}]=2,[+] /[-]=1.0$ ) prepared, as described above, with stock solutions of $\mathrm{MH}$ $\left(1 \mathrm{mg} \cdot \mathrm{mL}^{-1}\right), \quad \mathrm{CMD}-\mathrm{PEG} \quad\left(0.53 \mathrm{mg} \cdot \mathrm{mL}^{-1}\right), \mathrm{CaCl}_{2} \quad\left(0.54 \mathrm{mg} \cdot \mathrm{mL}^{-1}\right)$, in $10^{-2} \mathrm{M}$ Tris- $\mathrm{HCl}$ buffer, $\mathrm{pH}$ 7.4. The samples were kept at room temperature or at $37 \pm 0.5^{\circ} \mathrm{C}$ without protection against light. Samples containing $5 \% \mathrm{FBS}$ were prepared as well and kept at $37^{\circ} \mathrm{C}$. At different time intervals, aliquots of the solutions were analyzed by HPLC. The data presented are the mean of three measurements \pm S.D.

To assess the micelle integrity upon freeze-drying, $\mathrm{Ca}^{2+} / \mathrm{MH} /$ CMD-PEG micellar solutions ( $3 \mathrm{~mL}$, polymer concentration: $\left.0.1 \mathrm{mg} \cdot \mathrm{mL}^{-1} ;[+] /[-]=1.0,\left[\mathrm{Ca}^{2+}\right] /[\mathrm{MH}]=2\right)$ in a Tris- $\mathrm{HCl}$ buffer $\left(10^{-2} \mathrm{M}, \mathrm{pH}\right.$ 7.4) were frozen in a dry ice/acetone bath. They were lyophilized for $48 \mathrm{~h}$. The resulting powder was rehydrated with deionized water $(3 \mathrm{~mL})$ to reach a polymer concentration of $0.1 \mathrm{mg} \cdot \mathrm{mL}^{-1}$. The resulting micellar solution was magnetically stirred for $10 \mathrm{~min}$ and the $R_{\mathrm{H}}$ and $P D I$ of an aliquot were determined by DLS.

\section{Drug Release Studies}

Identical measurements were performed with solutions $(3.0 \mathrm{~mL})$ in Tris- $\mathrm{HCl}$ buffer $\left(10^{-2} \mathrm{M}, \mathrm{pH} 7.4,[\mathrm{NaCl}]=0\right.$ or $\left.0.15 \mathrm{M}\right)$ of $\mathrm{MH}, \mathrm{CaCl}_{2} /$ $\mathrm{MH}$, and $\mathrm{Ca}^{2+} / \mathrm{MH} / \mathrm{CMD}-\mathrm{PEG}$ micelles obtained as described above with a $2: 1 \mathrm{Ca}^{2+} /$ drug ratio, a $1: 1[+] /[-]$ ratio and $[\mathrm{MH}]=$ $0.75 \mathrm{mg} \cdot \mathrm{mL}^{-1}$. The solutions were introduced in a dialysis tube $(\mathrm{MWCO}=6-8 \mathrm{kDa})$. They were dialyzed against $150 \mathrm{~mL}$ of the same buffer at $37^{\circ} \mathrm{C}$. At predetermined time intervals, $3 \mathrm{~mL}$ aliquots were taken from the release medium and replaced by $3 \mathrm{~mL}$ of fresh buffer. The concentration of the drug was determined from the absorbance at $246 \mathrm{~nm}$ of the release medium samples and using a calibration curve. The cumulative percent of drug released was plotted as a function of dialysis time.

\section{Cell Survival and Nitrite Release Determinations}

Human hepatocytes were cultured in Human Hepatocyte Cell Culture Complete Media. Murine microglia (N9) cells were cultured in Iscove's Modified Dulbecco's Medium (IMDM) containing 5\% FBS and $1 \%$ penicillin-streptomycin. Cells were maintained at $37^{\circ} \mathrm{C}(5 \%$ $\left.\mathrm{CO}_{2}\right)$ in a humidified atmosphere. For the Alamar Blue assay, human hepatocytes and N9 cells were seeded in black, clear bottom 96-well plates (Corning) at a density of $5 \times 10^{4} \mathrm{cells} \cdot \mathrm{cm}^{-2}$ and $1 \times 10^{4}$ cells $\cdot \mathrm{cm}^{-2}$, respectively. For the MTT assay and nitrite measurement, hepatocytes and N9 cells were seeded in 24-well plates (Sarstedt, Montreal, OC, Canada) at a density of $5 \times 10^{4}$ cells $\cdot \mathrm{cm}^{-2}$ and $2 \times 10^{5}$ cells $\cdot \mathrm{cm}^{-2}$, respectively.

Cells were given fresh media (IMDM, 5\% FBS, 1\% penicillinstreptomycin for N9 cells; Human Hepatocyte Complete Media for hepatocytes) $24 \mathrm{~h}$ after seeding. They were treated with free $\mathrm{MH}$ $\left(50 \mu \mathrm{g} \cdot \mathrm{mL}^{-1}\right.$ ), the $\mathrm{Ca}^{2+} / \mathrm{MH}$ complex (dose equivalent to $50 \mu \mathrm{g} \cdot \mathrm{mL}^{-1} \mathrm{MH}$ ), $\mathrm{Ca}^{2+} / \mathrm{MH} / \mathrm{CMD}-\mathrm{PEG}$ micelles (dose equivalent to $50 \mu \mathrm{g} \cdot \mathrm{mL}^{-1} \mathrm{MH}$ ), or CMD-PEG $\left(0.1-15 \mathrm{mg} \cdot \mathrm{mL}^{-1}\right)$ with or without concomitant addition of lipopolysaccharides (LPS; $10 \mu \mathrm{g} \cdot \mathrm{mL}^{-1}$ ) for $24 \mathrm{~h}\left(37^{\circ} \mathrm{C}, 5 \% \mathrm{CO}_{2}\right.$, humidified atmosphere).

The Alamar Blue stock solution was diluted with fresh cell culture media to $10 \% \mathrm{v} / \mathrm{v}$ ratio. After cell treatment, media from each well were aspirated and $250 \mu \mathrm{L}$ of the Alamar Blue-media mixture were added to each well and incubated with the cells for $1 \mathrm{~h}$ at $37^{\circ} \mathrm{C}\left(5 \% \mathrm{CO}_{2}\right.$, humidified atmosphere). The intensity of fluorescence at $590 \mathrm{~nm}$ of the reduced resazurin (excitation wavelength: $544 \mathrm{~nm}$ ) was measured from the well bottom using a spectrofluorometer (FLUOStar OPTIMA). The percent viability was expressed as the fluorescence counts from treated samples over the untreated control. The colorimetric MTT assay was performed to assess the viability of N9 cells. One hour before the end of the treatment, MTT $\left(1.2 \times 10^{-5} \mathrm{M}\right.$, dissolved in sterile PBS) was added to the cells. Following a 1 -h incubation at $37^{\circ} \mathrm{C}$, media were removed, cells were lyzed, and formazan was dissolved with dimethylsulfoxide. The absorbance of the recovered formazan was measured at $595 \mathrm{~nm}$ using a Benchmark microplate reader (Bio-Rad, Mississauga, ON, Canada). All measurements were done in triplicates in three or more independent experiments. Nitric oxide (NO) release from N9 cells was measured using the Griess Reagent (1\% sulphanilamide, $0.1 \% \quad N$-(1-naphthyl)-ethylenediamine dihydrochloride, $5 \%$ phosphoric acid). After treatment, $50 \mu \mathrm{L}$ of the supernatant from each well were mixed with $50 \mu \mathrm{L}$ of Griess reagent in a clear bottom 96 -well plate, and incubated at room temperature for $15 \mathrm{~min}$. Absorbance at $548 \mathrm{~nm}$ of each sample was measured in triplicates using the microplate reader.

\section{Results and Discussion}

\section{Preparation, Characterization, and Stability of Ternary $\mathrm{Ca}^{2+} / \mathrm{MH} / \mathrm{CMD}-\mathrm{PEG}$ Nanoparticles}

At the onset of the study, it was important to confirm that the $2: 1 \mathrm{Ca}^{2+} / \mathrm{MH}$ chelates interact electrostatically with the carboxylate groups of CMD-PEG to form core-shell nanoparticles and that competing electrostatic interactions between $\mathrm{Ca}^{2+}$ and the polymer carboxylates do not disrupt 
the $\mathrm{Ca}^{2+}$ /drug chelation. ${ }^{1} \mathrm{H}$ NMR spectroscopy, DLS, and isothermal titration calorimetry (ITC) measurements were performed to address these issues. The ${ }^{1} \mathrm{H}$ NMR assay employed takes advantage of the fact that signals due to the resonance of low mobility protons broaden, and often cannot be detected at all, under conditions used to measure ${ }^{1} \mathrm{H}$ NMR spectra of soluble polymers. ${ }^{[33]}$ Thus, entrapment of the drug within the core of a micelle can be monitored readily by changes in the intensity and shape of ${ }^{1} \mathrm{H}$ NMR signals, as exemplified in Figure 2 which presents ${ }^{1} \mathrm{H}$ NMR spectra of solutions in $\mathrm{D}_{2} \mathrm{O}$ ( $\mathrm{pH}$ 7.4) of $\mathrm{MH}$, with spectral assignments taken from literature data, ${ }^{[34]}$ of the $2: 1 \mathrm{Ca}^{2+} /$
MH chelate, of CMD-PEG, and of a mixture of CMD-PEG and the $2: 1 \mathrm{Ca}^{2+} / \mathrm{MH}$ chelate. The composition of this mixture was such that the molar ratio, $[+] /[-]$, of positive charges provided by the $2: 1 \mathrm{Ca}^{2+} / \mathrm{MH}$ chelate to the negative charges provided by the diblock copolymer is equal to 1 (charge neutralization). Turning our attention first to the ${ }^{1} \mathrm{H}$ NMR spectrum of the chelate (Figure $2 \mathrm{~B}$ ), we note that upon binding of $\mathrm{MH}$ to $\mathrm{Ca}^{2+}$ the quartet due to the aromatic protons $\mathrm{H}_{8}$ and $\mathrm{H}_{9}$ decreases in intensity and new signals appear further downfield. The signal at $3.69 \mathrm{ppm}$ due to $\mathrm{H}_{4}$ is also affected significantly. These spectral shifts reflect conformational changes of $\mathrm{MH}$ upon chelation of $\mathrm{C}_{11}-\mathrm{C}_{12}-\mathrm{C}_{1}$

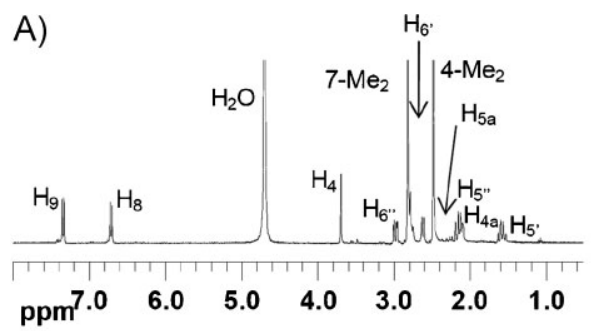

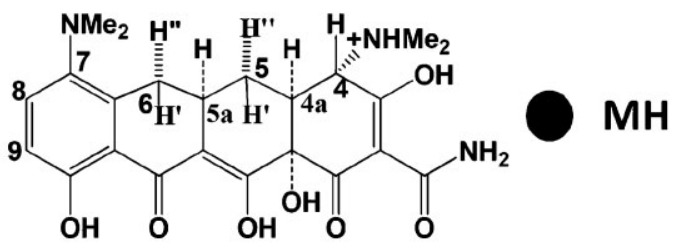
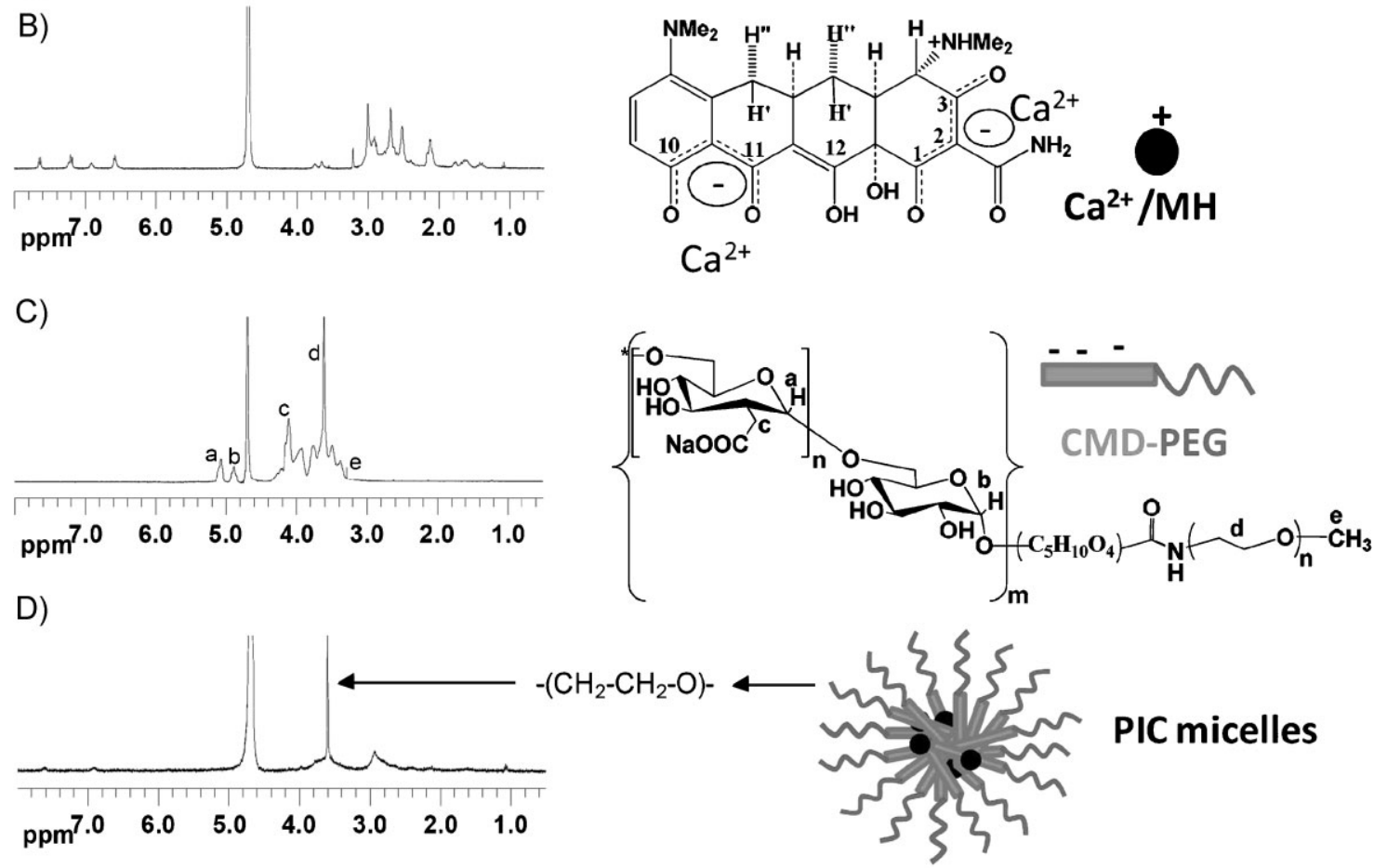

\section{PIC micelles}
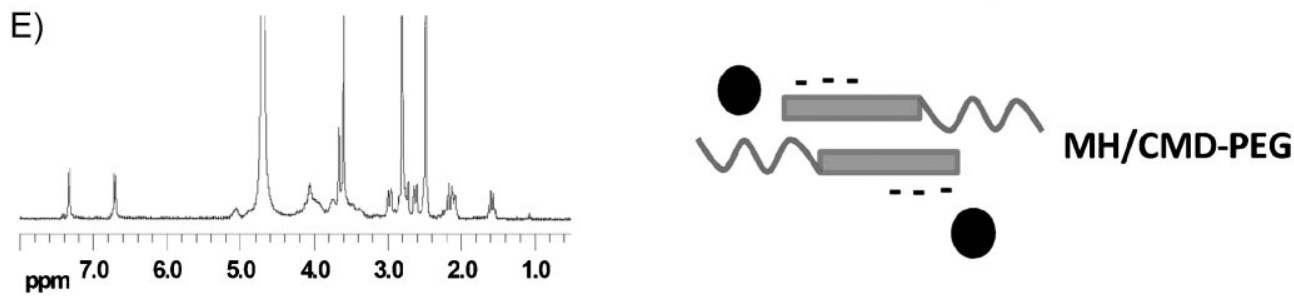

Figure 2. ' $\mathrm{H}$ NMR spectra of $\mathrm{MH}(\mathrm{A}), \mathrm{Ca}^{2+} / \mathrm{MH}, \quad\left(\left[\mathrm{Ca}^{2+}\right] /[\mathrm{MH}]=2.0\right)$ (B), CMD-PEG (C), $\mathrm{Ca}^{2+} / \mathrm{MH} / \mathrm{CMD}-\mathrm{PEG}$ (CMD-PEG concentration $\left.=2.0 \mathrm{mg} \cdot \mathrm{mL}^{-1},[+] /[-]=1.0,\left[\mathrm{Ca}^{2+}\right] /[\mathrm{MH}]=2.0\right)(\mathrm{D})$ and $\mathrm{MH} / \mathrm{CMD}-\mathrm{PEG}([+] /[-]=1.0)(\mathrm{E})$ in $\mathrm{D}_{2} \mathrm{O}$, room temperature, $\mathrm{pH} 7.4$ and representative illustrations of the species examined. 
carbonyl functionalities by the cations. ${ }^{[27]}$ The ${ }^{1} \mathrm{H}$ NMR spectrum of CMD-PEG (Figure 2C) presents signals at $\delta 4.08-$ $4.15,4.89$, and $5.07 \mathrm{ppm}$, ascribed to protons of the CMD block, and a broad strong singlet centered at $\delta 3.61 \mathrm{ppm}$ due to the PEG methylene protons $\left(-\mathrm{CH}_{2}-\mathrm{CH}_{2}-\mathrm{O}-\right)^{\left[{ }^{[32}\right]}$ The ${ }^{1} \mathrm{H}$ NMR spectrum of a mixed solution of the diblock copolymer and the drug chelate in amounts corresponding to charge neutralization (Figure 2D) is remarkably featureless: signals in the aromatic region due to the protons of chelated $\mathrm{MH}$ are undetectable. In the high field spectral range, one can observe a weak and broad signal $(\delta \approx 2.7-$ $3.0 \mathrm{ppm}$ ) that can be ascribed to $\mathrm{MH}$ protons with restricted motion and (ii) a strong singlet at $\delta 3.61 \mathrm{ppm}$ due to the PEG methylene protons. Signals due to the protons of the CMD block are undetectable. The preservation of the PEG signals, together with the disappearance of signals due to the drug chelate and to the CMD block, are diagnostic in indentifying the formation of nanoparticles with a $\mathrm{CMD} /$ drug chelate rigid core and a shell made up of flexible hydrated PEG chains. Figure $2 \mathrm{E}$ presents the ${ }^{1} \mathrm{H}$ NMR spectrum of a mixture of $\mathrm{MH}$ and CMD-PEG of drug and polymer concentrations identical to those of the ternary $\mathrm{Ca}^{2+} /$ MH/CMD-PEG system analyzed in Figure 2D. The signals of the drug and of the polymer are sharp and well resolved, confirming that, at $\mathrm{pH}$ 7.4, the drug does not interact with the polymer in the absence of $\mathrm{Ca}^{2+}$ ions.

${ }^{1} \mathrm{H}$ NMR spectra of $\mathrm{Ca}^{2+} / \mathrm{MH} / \mathrm{CMD}-\mathrm{PEG}$ mixtures of $[+] /$ $[-]>1.0$ (i.e. $[+] /[-]=1.25$ and 1.5) were recorded as well (Figure SI, supporting information). They present signals characteristic of the metal ion/MH complex in addition to signals due to the micelles, confirming that maximum drug loading is achieved at charge neutrality (i.e. $[+] /[-]=1.0$ ). The actual drug loading of the micelles at charge neutrality is identical to the theoretical drug loading, or ca. $50 \mathrm{wt}$. $\%$ of the micelles, since no signals of the free drug were detectable in the ${ }^{1} \mathrm{H}$ NMR spectrum of the micelles at charge neutrality (Figure 2D). This drug loading capacity is significantly higher than the capacity of other nanoparticulate carriers, such as liposomes ${ }^{[35]}$ and poly(lactide-coglycolide) (PLGA) nanoparticles, ${ }^{[36]}$ which usually have low encapsulation efficiencies for water soluble ionic drugs. High loading of drug delivery systems is highly desirable from the toxicological point of view, as it enhances the drug/excipients ratio and avoids overloading the body with unwanted chemicals.

To confirm the formation of nanoparticles upon mixing the $2: 1 \mathrm{Ca}^{2+} / \mathrm{MH}$ chelate and CMD-PEG, we analyzed by DLS a series of solutions in which the polymer concentration was kept constant $\left(0.2 \mathrm{mg} \cdot \mathrm{mL}^{-1}\right)$ while the $2: 1 \mathrm{Ca}^{2+} / \mathrm{MH}$ chelate concentration was increased such that the charge ratio in the mixture covered the $0<[+] /[-] \leq 2$ range. Mixed solutions of $[+] /[-]<0.5$ did not scatter light. In mixed solutions with a $[+] /[-]$ ratio of 0.5 , micellar objects were detected. They had a hydrodynamic radius $\left(R_{\mathrm{H}}\right)$ of $\approx 100 \mathrm{~nm}$ and $\mathrm{a} P \mathrm{PD}$ of $\approx 0.2$ (Figure $3 \mathrm{~A}$ ). In solutions of this composition, only part of the copolymer carboxylate groups is neutralized by the $\mathrm{Ca}^{2+} / \mathrm{MH}$ chelate. The repulsion between residual carboxylates prevents the formation of tight micelles. The $R_{\mathrm{H}}$ value of the micelles decreases to $\approx 80 \mathrm{~nm}$ as the $[+] /[-]$ ratio reaches 0.75 , a consequence of the progressive neutralization of the carboxylate groups by added $\mathrm{Ca}^{2+} / \mathrm{MH}$ chelate. For $[+] /[-]>0.75$, the micelle size gradually increases, indicating that additional metal ion/ drug complex is incorporated within the micelle core. The micelle $R_{\mathrm{H}}$ reaches $\approx 105 \mathrm{~nm}$ in solutions of $[+] /[-]=1.0$. For this composition, which will be used in further studies, the amount of $\mathrm{MH}$ incorporated in the micelles accounts for $\approx 50$ wt.-\% of the total micelles weight. The PDI of the micelle population was $\approx 0.1$ for $[+] /[-]>0.75$, indicating the formation of monodispersed nanoparticles.

The $\mathrm{Ca}^{2+} / \mathrm{MH} / \mathrm{CMD}-\mathrm{PEG}$ micelles $([+] /[-]=1.0, \mathrm{pH}=7.4)$ exhibited remarkable stability upon storage at room temperature for periods of 1 month, or longer. Their size and $P D I$ remained constant and no aggregation was
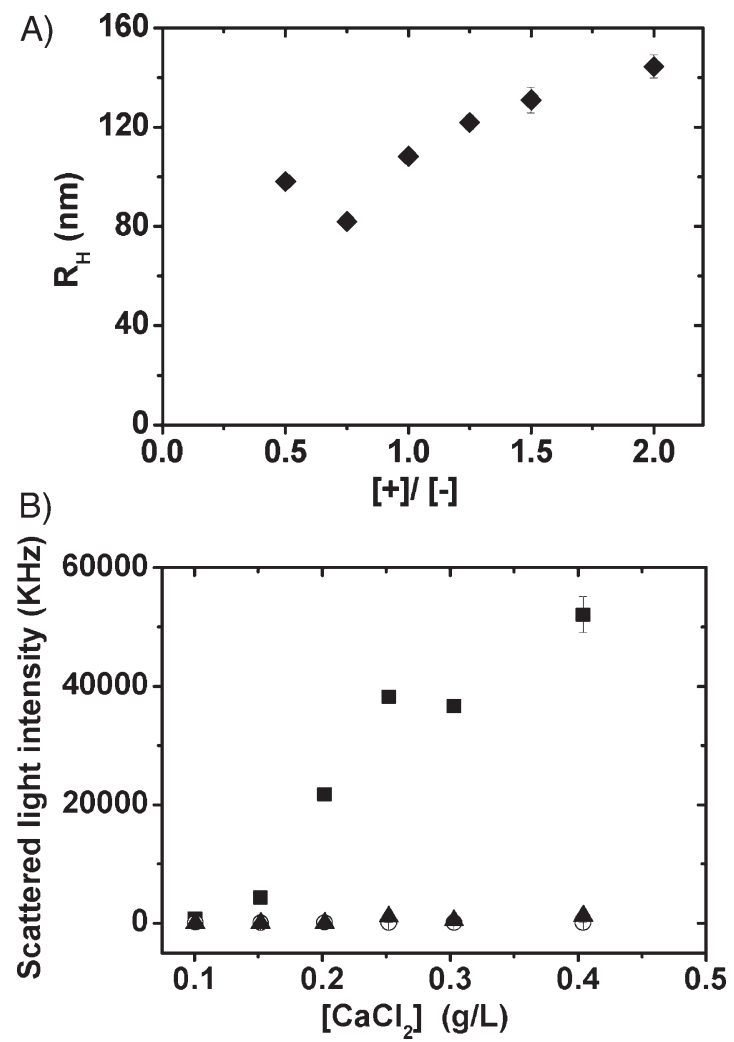

Figure 3. A: Hydrodynamic radius $\left(R_{\mathrm{H}}, \diamond\right)$ of $\mathrm{Ca}^{2+} / \mathrm{MH} / \mathrm{CMD}-\mathrm{PEG}$ micelles as a function of the [+]/[-] ratio; solvent: Tris- $\mathrm{HCl}$ buffer $\left(0,01 \mathrm{M}, \mathrm{pH} 7.4\right.$; CMD-PEG concentration: $0.2 \mathrm{mg} \cdot \mathrm{mL}^{-1},\left[\mathrm{Ca}^{2+}\right] /$ $[\mathrm{MH}]=2)$. B: Scattered light intensity as a function of calcium chloride concentration from solutions of $\mathrm{Ca}^{2+} / \mathrm{MH} / \mathrm{CMD}-\mathrm{PEC}$ micelles ( $\boldsymbol{\square}), \mathrm{Ca}^{2+} / \mathrm{MH}(\boldsymbol{\Delta})$ and $\mathrm{Ca}^{2+} / \mathrm{CMD}-\mathrm{PEG}(\mathrm{O})$; solvent: Tris- $\mathrm{HCl}$ buffer $(0,01 \mathrm{M}, \mathrm{pH}$ 7.4), CMD-PEG concentration: $0.2 \mathrm{mg} \cdot \mathrm{mL}^{-1}$. 
detected. Moreover, micellar solutions of $\mathrm{Ca}^{2+} / \mathrm{MH} / \mathrm{CMD}$ PEG were readily reconstituted after freeze drying by simple solubilization in water of the lyophilized powder, even in the absence of cryoprotectants. Upon re-dissolution, the micelles recovered their size $\left(R_{\mathrm{H}} \approx 100 \mathrm{~nm}\right)$ and colloidal stability. The micelles stability upon freeze drying and reconstitution is an important criterion for a pharmaceutically viable formulation, since the shelf life of a drug formulation in the powder form tends to be much longer than in solution. Also powders are easier to handle, store and transfer.

Control experiments were carried out to confirm that addition of $\mathrm{Ca}^{2+}$ to a solution of either CMD-PEG or MH does not trigger the formation of nanoparticles. The intensity of light scattered at an angle of $90^{\circ}$ was determined as a function of added $\mathrm{Ca}^{2+}$ for solutions of increasing $\left[\mathrm{Ca}^{2+}\right]$ in the ternary $\mathrm{Ca}^{2+} / \mathrm{MH} / \mathrm{CMD}-\mathrm{PEG}$ system and in the binary systems $\mathrm{Ca}^{2+} / \mathrm{CMD}-\mathrm{PEG}$ and $\mathrm{Ca}^{2+} / \mathrm{MH}$ (Figure 3B). For the ternary system, the scattered light intensity underwent a sharp increase for $\left[\mathrm{Ca}^{2+}\right]>$ $0.15 \mathrm{mg} \cdot \mathrm{mL}^{-1}([+] /[-]=0.75)$, an indication of the presence of micelles which, given their size, scatter light extensively. The intensity of scattered light for mixtures of either $\mathrm{Ca}^{2+}$ / CMD-PEG or $\mathrm{Ca}^{2+} / \mathrm{MH}$ mixtures was weak, independently of $\left[\mathrm{Ca}^{2+}\right]$. These results, together with the ${ }^{1} \mathrm{H}$ NMR results, confirm that PIC micelles incorporating $\mathrm{MH}$ only form in the presence of both the polymer and $\mathrm{Ca}^{2+}$. The association constants of $\mathrm{Ca}^{2+} / \mathrm{MH}$ and $\mathrm{Ca}^{2+} / \mathrm{CMD}-\mathrm{PEG}$, $8.9 \pm 0.7 \times 10^{4} \mathrm{M}^{-1}$ and $1.17 \pm 0.03 \times 10^{4} \mathrm{M}^{-1}$, respectively, determined by ITC, indicate that the affinity of $\mathrm{Ca}^{2+}$ ions for $\mathrm{MH}$ is ca. 8 times higher than that for CMD-PEG (Supporting Information). Therefore, in tertiary mixtures of $\mathrm{Ca}^{2+}$ / $\mathrm{MH} / \mathrm{CMD}-\mathrm{PEG}, \mathrm{Ca}^{2+}$ ions preferentially bind to $\mathrm{MH}$.

\section{Stability and Release of $\mathrm{MH}$ entrapped in $\mathrm{Ca}^{2+} / \mathrm{MH} / \mathrm{CMD}-\mathrm{PEG}$ Nanoparticles $([+] /[-]=1.0, \mathrm{pH}$ 7.4)}

$\mathrm{MH}$ is known to degrade rapidly in aqueous solutions exposed to ambient light and temperature. A number of studies have shown that chelation of $\mathrm{MH}$ with $\mathrm{Ca}^{2+}$ significantly enhances the stability of the drug in solution. ${ }^{[12,29]}$ It was important to confirm that the stabilizing effect of $\mathrm{Ca}^{2+}$ was preserved upon binding of the chelate to CMD-PEG and subsequent micellization. We set about to determine the changes, as a function of storage time, of the $\mathrm{MH}$ concentration in solutions of ternary $\mathrm{Ca}^{2+} / \mathrm{MH} / \mathrm{CMD}-\mathrm{PEG}$ micelles
$([+] /[-]=1.0, \mathrm{pH}=7.4)$ and to compare it to $[\mathrm{MH}]$ in solutions of the drug alone, $\mathrm{MH} / \mathrm{CMD}-\mathrm{PEG}$ mixtures and the $2: 1 \mathrm{Ca}^{2+} / \mathrm{MH}$ chelate stored under the same conditions. We used a standard HPLC assay for the quantitative analysis of

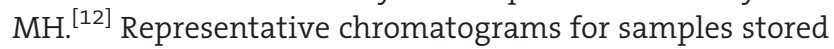
at room temperature are depicted in Figure 4. From the chromatograms of the solution of $\mathrm{MH}$ alone recorded after various storage periods (Figure 4A), one can conclude that after about 2 weeks, nearly all the drug has degraded into several faster eluting derivatives, as reported previously. ${ }^{[12]}$ The same behavior was observed for the MH/CMD-PEG mixture (Figure $4 \mathrm{~B}$ ), confirming the NMR and DLS results that the polymer does not interact with $\mathrm{MH}$ in the absence of metal ions. Chromatograms recorded for the $\mathrm{Ca}^{2+} / \mathrm{MH}$ chelate solution (Figure 4C) display a band corresponding to $\mathrm{MH}$, as the main component, even after 3 weeks of storage. Chromatograms of solutions stored for 2 weeks or more present in addition a weak slower eluting band, attributed to the $\mathrm{MH} \mathrm{C}_{4}$ epimer based on previous studies. ${ }^{[12,37]}$ Chromatograms corresponding to solutions of $\mathrm{Ca}^{2+} / \mathrm{MH} /$ CMD-PEG micelles $([+] /[-]=1.0)$ are presented in Figure 4D. Their features are similar to those of the chromatograms recorded for the $\mathrm{Ca}^{2+} / \mathrm{MH}$ chelate solutions, confirming that the enhanced stability provided to the drug by $\mathrm{Ca}^{2+}$ is not affected upon incorporation of the chelate in polymer micelles. We note that the intensity of the band ascribed to the elution of the $\mathrm{MH} \mathrm{C}_{4}$ epimer is slightly weaker in the chromatograms recorded for micellar solutions, compared to solutions of the $\mathrm{Ca}^{2+} / \mathrm{MH}$ chelate. This observation gives some indication that the $\mathrm{MH}$
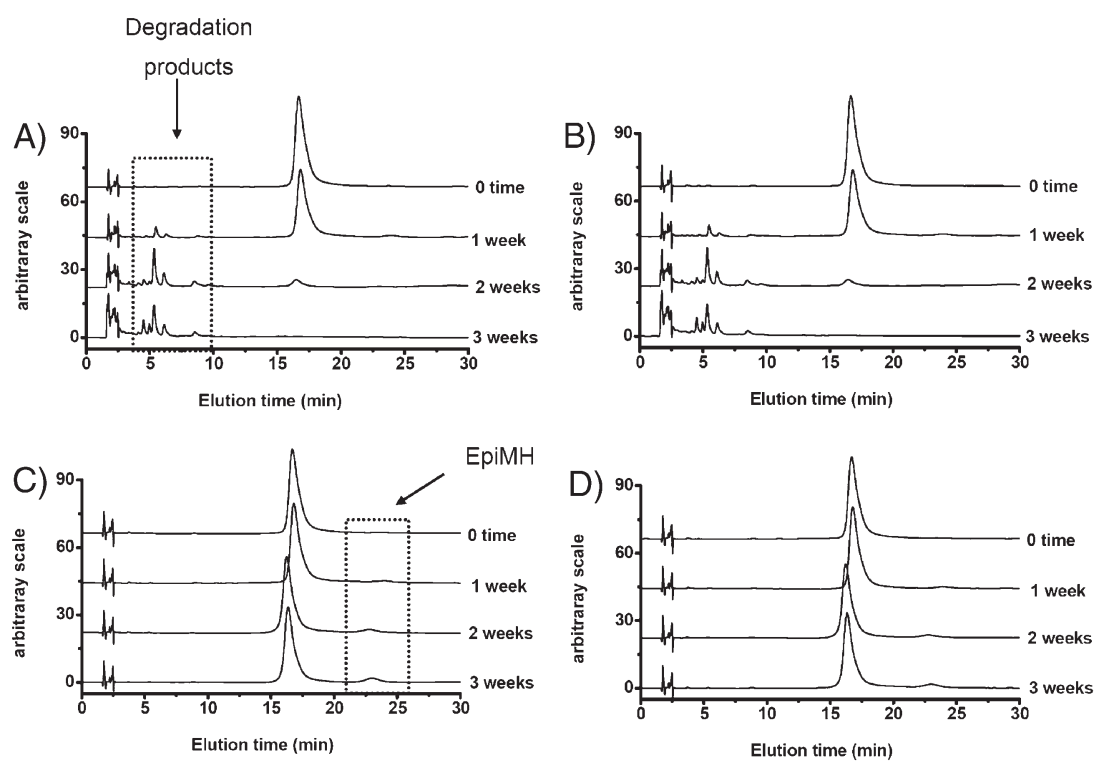

Figure 4. Chromatograms recorded upon storage at room temperature for up to 3 weeks of $\mathrm{MH}$ in Tris- $\mathrm{HCl}$ buffer (o,01 $\mathrm{M}, \mathrm{pH} 7.4)(\mathrm{A}), \mathrm{MH} / \mathrm{CMD}-\mathrm{PEG}(\mathrm{B}), \mathrm{Ca}^{2+} / \mathrm{MH}\left(\left[\mathrm{Ca}^{2+}\right] /\right.$ $[\mathrm{MH}]=2.0)(\mathrm{C}), \mathrm{Ca}^{2+} / \mathrm{MH} / \mathrm{CMD}-\mathrm{PEG}\left([+] /[-]=1.0,\left[\mathrm{Ca}^{2+}\right] /[\mathrm{MH}]=2.0\right)(\mathrm{D}),[\mathrm{CMD}-$ $\mathrm{PEG}]=0.1 \mathrm{mg} \cdot \mathrm{mL}^{-1}$. For elution conditions: see Experimental Part. 
Table 1. Residual percent of $\mathrm{MH}$ upon storage at room temperature of various formulations of the drug in Tris- $\mathrm{HCl}$ buffer of $\mathrm{pH}$ 7.4 .

\begin{tabular}{|c|c|c|c|c|}
\hline Time & $\mathbf{M H}^{\mathrm{a})}$ & $\begin{array}{c}\text { MH/ } \\
\left.\text { CMD-PEG }^{b}\right)\end{array}$ & $\begin{array}{l}\mathrm{Ca}^{2+} / \\
\mathrm{MH}^{\mathrm{c})}\end{array}$ & $\begin{array}{c}\mathrm{Ca}^{2+} / \mathrm{MH} / \\
\left.\mathrm{CMD}-\mathrm{PEG}^{\mathrm{c}) \mathrm{d}}\right)\end{array}$ \\
\hline 0 & $99.7 \pm 1.9$ & $100.5 \pm 0.6$ & $102 \pm 0.5$ & $98.4 \pm 1.2$ \\
\hline 1 & $99.3 \pm 1.4$ & $101.1 \pm 0.2$ & $98 \pm 1.2$ & $98.9 \pm 1.3$ \\
\hline 7 & $73.6 \pm 0.4$ & $72.6 \pm 0.6$ & $92.5 \pm 0.6$ & $98.3 \pm 0.8$ \\
\hline 14 & $7.8 \pm 0.6$ & $7.6 \pm 0.5$ & $90.6 \pm 1.4$ & $96.3 \pm 0.7$ \\
\hline 21 & & & $84.2 \pm 0.9$ & $90.9 \pm 1.2$ \\
\hline 28 & & & $80.9 \pm 1.1$ & $86.3 \pm 1.3$ \\
\hline 35 & & & $75.1 \pm 0.9$ & $81.5 \pm 0.9$ \\
\hline 42 & & & $72.0 \pm 0.1$ & $77.3 \pm 1.8$ \\
\hline 56 & & & $64.6 \pm 1.4$ & $73.4 \pm 2.3$ \\
\hline 96 & & & $48.4 \pm 3.0$ & $68.2 \pm 0.6$ \\
\hline
\end{tabular}

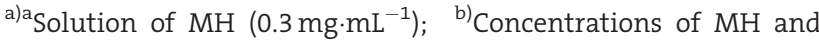
CMD-PEG are the same as those in $\mathrm{Ca}^{2+} / \mathrm{MH} / \mathrm{CMD}-\mathrm{PEG}$ micelles; ${ }^{c}\left[\mathrm{Ca}^{2+}\right] /[\mathrm{MH}]=2.0 .{ }^{\mathrm{d})}[+] /[-]=1.0$.

epimerization at $\mathrm{C}_{4}$ is somewhat slower when the $\mathrm{Ca}^{2+} / \mathrm{MH}$ chelate is entrapped within micelles, possibly as a consequence of CMD-PEG/MH chelate electrostatic interactions that may take place within the micellar core. The drug stability at $37^{\circ} \mathrm{C}$ was lower than at room temperature. Nonetheless, the CMD-PEG copolymer still acts as a protective environment for the metal ion/drug complex. The concentrations of $\mathrm{MH}$ in solutions of $\mathrm{MH}$ alone, of $\mathrm{Ca}^{2+}$ chelated $\mathrm{MH}$, and the micellar formulation are listed in Table 1 and Table 2 for various times during a 3-month period of storage at room temperature and at $37^{\circ} \mathrm{C}$.

Next, in an attempt to simulate the environment of the drug upon injection in vivo, we assessed the stability of $\mathrm{MH}$ in formulations incubated at $37^{\circ} \mathrm{C}$ in the presence of serum proteins. Addition of serum greatly enhances the stability of uncomplexed $\mathrm{MH}$. Similar effects were reported previously in the case of drugs such as curcumin and attributed to the formation of protein/drug complexes. ${ }^{[38]} \mathrm{MH}$ is known for its affinity to interact with serum proteins. ${ }^{[39]}$ The micellar constructs maintained their protective effects even in the presence of serum proteins: after a 7-day incubation at $37^{\circ} \mathrm{C}$ with serum, $\approx 75 \%$ of the drug was intact when complexed within $\mathrm{Ca}^{2+} / \mathrm{MH} / \mathrm{CMD}-\mathrm{PEG}$ micelles, whereas only $\approx 30 \%$ of the drug was still present in a sample of free drug treated in the same conditions (Table 2).

We conducted also in vitro drug release studies in order to assess the suitability of the micelles to act as drug delivery systems. The release of $\mathrm{MH}$ from $\mathrm{Ca}^{2+} / \mathrm{MH} / \mathrm{CMD}-\mathrm{PEG}$ micelles was evaluated by the dialysis bag method, coupled with quantitative analysis of the drug using its UV absorbance at $246 \mathrm{~nm}$ (Figure 5). ${ }^{[40]}$ The micelles released $\approx 50 \%$ and $75 \%$ drug after $8 \mathrm{~h}$ and $24 \mathrm{~h}$, respectively. The drug release from the micelles was slightly faster under physiological salt concentrations $(0.15 \mathrm{M} \mathrm{NaCl})$, which may be attributed to the weakening of the electrostatic interactions between $\mathrm{Ca}^{2+} / \mathrm{MH}$ and $\mathrm{CMD}-\mathrm{PEG}$ upon addition of salt. ${ }^{[19,32]}$ Control experiments carried out with a solution of the $\mathrm{Ca}^{2+} / \mathrm{MH}$ chelate revealed that drug release from this solution was significantly faster than from a $\mathrm{Ca}^{2+} / \mathrm{MH} / \mathrm{CMD}-\mathrm{PEG}$ micellar solution (Figure 5 ). After $8 \mathrm{~h}$, $\approx 88 \%$ of the drug was released in the case of $\mathrm{Ca}^{2+} / \mathrm{MH}$ solution, whereas for micellar solutions only $50 \%$ drug was released after the same time. The sustained $\mathrm{MH}$ release from the micelles is expected to reduce the frequency of its administration, which results in fewer side effects and better patient compliance.

Next, we monitored by DLS the fate of $\mathrm{Ca}^{2+} / \mathrm{MH} / \mathrm{CMD}$ PEG micelles, first, in the presence of BSA, and, second, in the presence of $5 \%$ fetal bovine serum. Although the interactions of the micelles with serum are the most relevant to the situation in vivo, BSA, which is the most abundant protein

Table 2. Residual percent of $\mathrm{MH}$ upon storage at $37^{\circ} \mathrm{C}$ of various formulations of the drug in Tris- $\mathrm{HCl}$ buffer of $\mathrm{pH} 7.4$ and in the same buffer containing $5 \%$ FBS.

\begin{tabular}{|c|c|c|c|c|c|c|}
\hline \multirow{2}{*}{$\begin{array}{l}\text { Time } \\
d\end{array}$} & \multicolumn{2}{|c|}{$\mathbf{M H}^{\mathrm{a})}$} & \multicolumn{2}{|c|}{$\mathrm{Ca}^{2+} / \mathrm{MH}^{\mathrm{b})}$} & \multicolumn{2}{|c|}{$\mathrm{Ca}^{2+} / \mathrm{MH} / \mathrm{CMD}^{2} \mathrm{PEG}^{\mathrm{b}) \mathrm{c})}$} \\
\hline & No serum & $5 \%$ serum & No serum & $\mathbf{5 \%}$ serum & No serum & $5 \%$ serum \\
\hline 0 & $102.3 \pm 1.3$ & $97.1 \pm 1.3$ & $98.9 \pm 1.6$ & $98.3 \pm 1.4$ & $98.1 \pm 1.3$ & $96.6 \pm 0.5$ \\
\hline 1 & $96.8 \pm 0.7$ & $95.0 \pm 0.7$ & $92.9 \pm 0.9$ & $92.6 \pm 1.5$ & $90.5 \pm 0.8$ & $89.5 \pm 1.7$ \\
\hline 7 & $3.5 \pm 0.0$ & $31.5 \pm 0.8$ & $64.9 \pm 2.4$ & $76.4 \pm 0.6$ & $66.6 \pm 1.0$ & $74.0 \pm 2.9$ \\
\hline 16 & - & $20.6 \pm 0.0$ & $59.0 \pm 3.7$ & $65.5 \pm 1.7$ & $67.9 \pm 5.7$ & $69.7 \pm 2.4$ \\
\hline 22 & - & & $56.6 \pm 1.6$ & $60.7 \pm 0.5$ & $66.6 \pm 0.5$ & $66.6 \pm 0.3$ \\
\hline 29 & - & & $47.6 \pm 1.0$ & $61.5 \pm 0.7$ & $60.4 \pm 0.7$ & $63.3 \pm 0.6$ \\
\hline
\end{tabular}

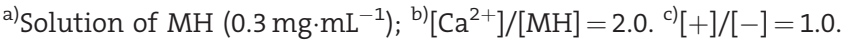




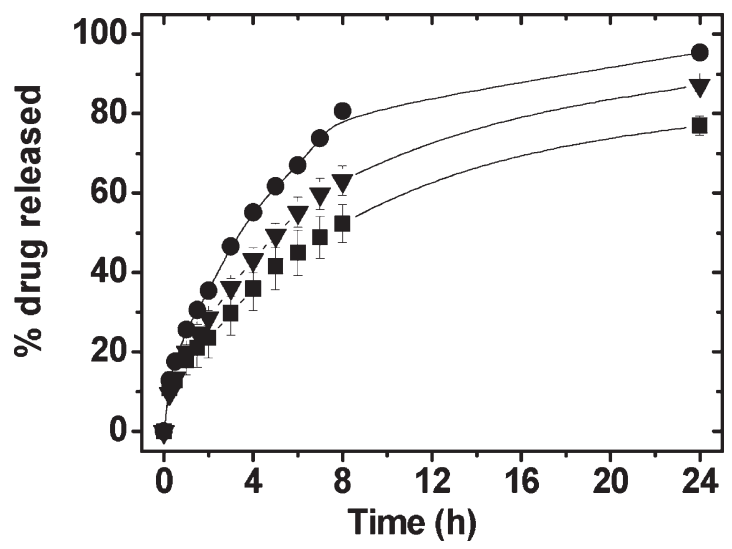

Figure 5. Release profiles for $\mathrm{MH}$ kept at $37^{\circ} \mathrm{C}$ in Tris- $\mathrm{HCl}$ buffer $\left(10 \times 10^{-3} \mathrm{M}, \mathrm{pH} 7.4\right)$ in the case of $\mathrm{Ca}^{2+} / \mathrm{MH}(\mathbf{)}) \mathrm{Ca}^{2+} / \mathrm{MH} / \mathrm{CMD}$ PEG $[\mathrm{NaCl}]=\mathrm{O}(\boldsymbol{\square})$ and $\mathrm{Ca}^{2+} / \mathrm{MH} / \mathrm{CMD}-\mathrm{PEG}[\mathrm{NaCl}]=0.150 \mathrm{M}(\boldsymbol{\nabla})$. $[+] /[-]$ for micelles $=1.0$ and $\left[\mathrm{Ca}^{2+}\right] /[\mathrm{MH}]=2.0$.

is serum, is often used as a model since its size and conformation are known precisely. ${ }^{[41]}$ The intensity fraction distribution of the $R_{\mathrm{H}}$ of $\mathrm{Ca}^{2+} / \mathrm{MH} / \mathrm{CMD}-\mathrm{PEG}$ micellar solutions ([CMD-PEG]: $0.2 \mathrm{mg} \cdot \mathrm{mL}^{-1},[+] /[-]=1.0$ ) and various amounts of BSA, from 0 to $40 \mathrm{mg} \cdot \mathrm{mL}^{-1}$, are presented in Figure 6A. The $R_{\mathrm{H}}$ of BSA under the measurement conditions ( $5 \mathrm{mg} \cdot \mathrm{mL}^{-1}, \mathrm{pH} 7.4$ ) was $4.2 \pm 0.1 \mathrm{~nm}$, in agreement with reported values (Figure 6A, top trace). ${ }^{[41,42]}$ The $R_{\mathrm{H}}$ value of $\mathrm{Ca}^{2+} / \mathrm{MH} / \mathrm{CMD}-\mathrm{PEG}$ micelles in the absence of BSA was $84 \pm 2 \mathrm{~nm}$ (Figure 6A, bottom trace). The presence of a signal $\approx 4 \mathrm{~nm}$ in all $\mathrm{BSA} /$ micelle mixed systems, together with a signal $\approx 90 \mathrm{~nm}$ indicates that the micelle integrity is preserved in the presence of BSA. The micellar size distribution in solutions of highest BSA concentration is slightly broader than in solutions devoid of BSA, possibly as a consequence of some level of BSA adsorption onto the micelles. BSA, which is negatively charged under physiological conditions ( $\mathrm{pH}$ 7.4) could act as competing polyelectrolyte for PIC micelles and polyelectrolyte complexes. ${ }^{[19,43]}$ The stability of $\mathrm{Ca}^{2+} / \mathrm{MH} / \mathrm{CMD}$ PEG micelles in the presence of BSA concentration as high as 100 times the polymer concentration is probably a consequence of the limited access of negatively charged BSA to the positively charged $\mathrm{Ca}^{2+} / \mathrm{MH}$ chelate due to its entrapment in the micelles core. DLS analysis of $\mathrm{Ca}^{2+} / \mathrm{MH} /$ CMD-PEG micelles incubated for $24 \mathrm{~h}$ at $37{ }^{\circ} \mathrm{C}$ with $5 \% \mathrm{FBS}$ also revealed the presence of two size populations (Figure 6B): (i) small objects of $R_{\mathrm{H}} \approx 7 \mathrm{~nm}$, identified as serum proteins by comparison with the serum DLS data (Figure 6B, top trace) and (ii) larger objects of $R_{\mathrm{H}}$, identical, within experimental uncertainty, to the $R_{\mathrm{H}}$ of micelles incubated under the same conditions, but in the absence of serum (Figure 6B, bottom trace). These observations confirm that the micelles withstand the serum environment and that protein adsorption onto micelles occurs to a limited extent, if at all. ${ }^{[44]}$
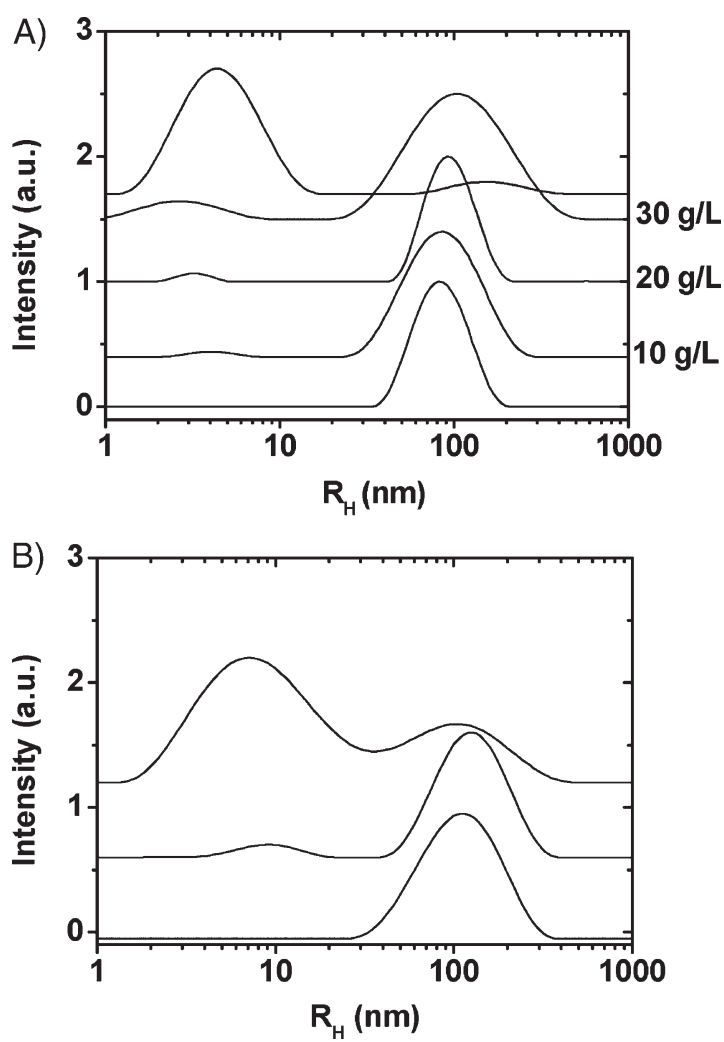

Figure 6. A: Normalized size distributions of $\mathrm{Ca}^{2+} / \mathrm{MH} / \mathrm{CMD}-\mathrm{PEG}$ micelles upon incubation at $37^{\circ} \mathrm{C}$ for $15 \mathrm{~h}$ with various amounts of BSA. Also shown are the size distributions recorded for micelles alone (bottom trace) and BSA alone $\left(5 \mathrm{mg} \cdot \mathrm{mL}^{-1}\right)$ (top trace); $[+] /[-]$ for micelles $=1.0$ and $\left[\mathrm{Ca}^{2+}\right] /[\mathrm{MH}]=2.0$. B: Normalized size distribution of $\mathrm{Ca}^{2+} / \mathrm{MH} / \mathrm{CMD}-\mathrm{PEG}$ micelles upon incubation at $37^{\circ} \mathrm{C}$ for $24 \mathrm{~h}$ with $5 \%$ serum; also shown are the size distributions of micelles alone after incubation for $24 \mathrm{~h}$ at $37^{\circ} \mathrm{C}$ (bottom trace) and of $5 \%$ serum alone (top trace); $[+] /[-]$ for micelles $=1.0$ and $\left[\mathrm{Ca}^{2+}\right] /[\mathrm{MH}]=2.0$.

\section{Cytotoxicity and Anti-Inflammatory Effects of $\mathrm{Ca}^{2+}$, MH/CMD-PEG Micelles}

The cytotoxic effect of CMD-PEG on the viability of human hepatocytes and murine microglia was evaluated by the MTT and Alamar Blue assays and confirmed by cell counting. Hepatocytes were selected since the liver represents the main organ in which biotransformation of drugs and foreign substances takes place, while the inflamed microglia are the main targets of the drug in the central nervous system. ${ }^{[45]}$ Cell viability did not change significantly after a $24 \mathrm{~h}$-incubation with CMD-PEG up to a concentration of $15 \mathrm{mg} \cdot \mathrm{mL}^{-1}$ (Figure SII, Supporting Information). The concentrations of CMD-PEG assessed were within the theoretical concentration range needed to achieve clinically relevant minocycline concentrations. It is anticipated that the PEG corona will prolong the micelles circulation in blood and reduce their uptake in the liver, as demonstrated previously with other PEGylated micelles. ${ }^{[46]}$ 
The usefulness of micelle-entrapped $\mathrm{MH}$ for attenuation of microglia activity was tested in N9 microglia cells treated with lipopolysaccharides, (LPS), which are known inducers of microglia activation leading to the release of cytokines and nitric oxide. ${ }^{[4]}$ Minocycline can inhibit the LPS-induced microglia activation and, in turn, reduce the amount of nitric oxide (NO) released. ${ }^{[48,49]}$ In the murine microglia (N9) model, a LPS dose of $10 \mu \mathrm{g} \cdot \mathrm{mL}^{-1}$ induced significant release of NO after $24 \mathrm{~h}(3.8 \pm 0.1$ a.u. compared to the untreated control (Figure 7)). The cells were subjected to concomitant treatments with $10 \mu \mathrm{g} \cdot \mathrm{mL}^{-1}$ LPS and $50 \mu \mathrm{g} \cdot \mathrm{mL}^{-1} \mathrm{MH}$ in three formulations: $\mathrm{MH}, \mathrm{Ca}^{2+} / \mathrm{MH}$, and $\mathrm{Ca}^{2+} / \mathrm{MH} / \mathrm{CMD}-\mathrm{PEG}$ micelles or with $10 \mu \mathrm{g} \cdot \mathrm{mL}^{-1} \mathrm{LPS}$ and $10 \mathrm{mg} \cdot \mathrm{mL}^{-1} \mathrm{CMD}-\mathrm{PEG}$, in the absence of $\mathrm{MH}$. As expected, $\mathrm{MH}$ alone greatly reduced the $\mathrm{NO}$ release $(0.3 \pm 0.01$ a.u.). A similar effect was induced by $\mathrm{Ca}^{2+} / \mathrm{MH} / \mathrm{CMD}-\mathrm{PEG}$ micelles and by $\mathrm{Ca}^{2+} / \mathrm{MH}$ chelate at concentrations equivalent to $50 \mu \mathrm{g} \cdot \mathrm{mL}^{-1}$ (Figure 7). This result confirms that $\mathrm{MH}$ is released from the micelles in a pharmacologically active form and that the presence of the polymer or of $\mathrm{CaCl}_{2}$ does not affect the drug activity. Unexpectedly, a control measurement that involved concomitant administration of LPS and CMD-PEG revealed that the polymer itself reduced NO release by $\approx 60 \%$, compared to NO release level of the control measurement in the absence of CMD-PEG. If such an effect could be obtained in animal models and eventually in humans it could be of a significant relevance for improvement of minocycline effectiveness in an additive or even synergistic manner. We are currently pursuing these studies to assess if this polymer indeed does not only serve as a drug carrier but can also enhance beneficial anti-inflammatory effect of minocycline and other antiinflammatory agents. The exact mechanism of this

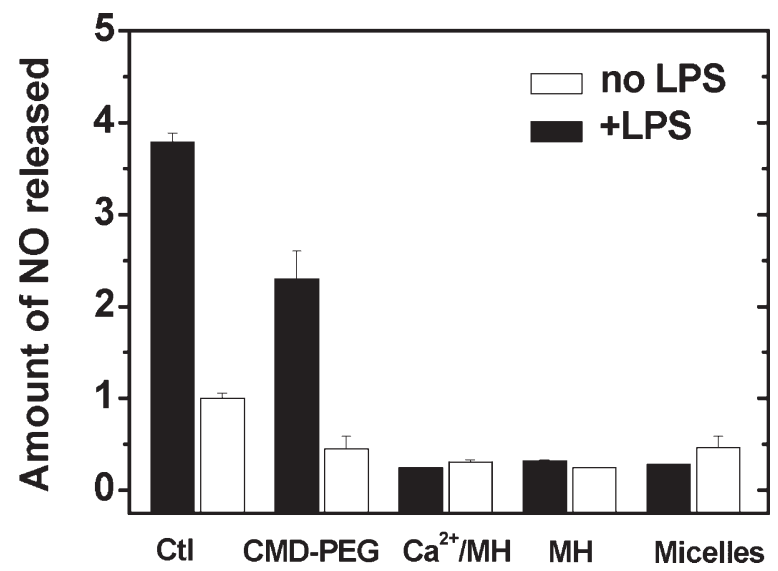

Figure 7. Amount of $\mathrm{NO}$ released in $\mathrm{Ng}$ microglia cells treated with $\mathrm{MH}$ alone, $\mathrm{Ca}^{2+} / \mathrm{MH}$ complex, $\mathrm{Ca}^{2+} / \mathrm{MH} / \mathrm{CMD}-\mathrm{PEG}$ micelles or CMD-PEG, all in the presence or absence of $10 \mu \mathrm{g} \cdot \mathrm{mL}^{-1}$ of LPS under normal cell culture conditions. Cells were treated for $24 \mathrm{~h}$ after which nitrite content in the media was measured using the Griess Reagent. All measurements were done in triplicates in three independent experiments. polymer-induced reduction in NO release is not clear and requires further investigations.

\section{Conclusion}

Complexation of the minocycline calcium chelate into CMD-PEG PIC micelles leads to a significant drug stabilization upon storage and in the presence of serum under physiological conditions. A similar approach may be suitable for other antibiotics and therapeutic agents whose stability can be increased in this manner. Preliminary in vitro results indicate that while encapsulating $\mathrm{MH}$ into $\mathrm{Ca}^{2+} / \mathrm{MH} / \mathrm{CMD}-\mathrm{PEG}$ micelles has its own merit in stabilizing the drug, controlling its release, and reducing protein adsorption, neither $\mathrm{CaCl}_{2}$ nor the polymer negatively affect the anti-inflammatory activity of the drug. These observations need to be strengthened by in vivo investigations aimed at assessing if such formulations permit administration of MH in smaller but still effective doses which could significantly reduce the extent and severity of its undesirable side effects.

Acknowledgements: The work was supported in part by a grant of the Natural Sciences and Engineering Research Council of Canada to F.M.W. and D.M. and by a grant of the Canadian Institutes of Health Research to D.M. G.M.S. thanks the Ministry of Higher Education, Egypt for granting him a scholarship.

Received: July 13, 2009; Revised: September 1, 2009; Published online: November 20, 2009; DOI: 10.1002/mabi.200900259

Keywords: block copolymers; drug delivery systems; micelles; particle size distribution; polyelectrolytes

[1] D. Blum, A. Chtarto, L. Tenenbaum, J. Brotchi, M. Levivier, Neurobiol. Dis. 2004, 17, 359.

[2] A. L. F. Bernardino, D. Kaushal, M. T. Philipp, J. Infect. Dis. 2009, 199, 1379.

[3] J. Yrjanheikki, T. Tikka, R. Keinanen, G. Goldsteins, P. H. Chan, J. Koistinaho, Proc. Natl. Acad. Sci. U. S. A. 1999, 96, 13496.

[4] H. S. Kim, Y. H. Suh, Behav. Brain Res. 2009, 196, 168.

[5] M. A. Yenari, L. J. Xu, X. N. Tang, Y. L. Qiao, R. G. Giffard, Stroke 2006, 37, 1087.

[6] P. Rio-Hortega, "Microglia", in: Cytology and cellular pathology of the nervous system, W. Penfield, Ed., Hocker, New York 1932, p. 481.

[7] M. L. Block, L. Zecca, J.-S. Hong, Nat. Rev. Neurosci. 2007, 8, 57.

[8] N. C. Klein, B. A. Cunha, Med. Clin. N. Am. 1995, 79, 789.

[9] A. Di Stefano, P. Sozio, A. Iannitelli, L. S. Cerasa, A. Fontana, G. Di Biase, G. D’Amico, M. Di Giulio, C. Carpentiero, L. Grumetto, F. Barbato, Eur. J. Pharm. Sci. 2008, 34, 118.

[10] S. C. Fagan, D. J. Edwards, C. V. Borlongan, L. Xu, A. Arora, G. Feuerstein, D. C. Hess, Exp. Neurol. 2004, 186, 248. 
[11] V. Zbinovsky, G. P. Chrekian, "Minocycline", in: Analytical Profiles of Drug Substances, K. Florey, Ed., Academic Press, New York 1977, p. 323.

[12] K. T. Chow, L. W. Chan, P. W. S. Heng, Pharm. Res. 2008, $25,207$.

[13] A. Barry, R. Badal, Curr. Microbiol. 1978, 1, 33.

[14] N. Jain, G. K. Jain, F. J. Ahmad, R. K. Khar, Anal. Chim. Acta 2007, 599, 302.

[15] B. Rasmussen, H. F. Noller, G. Daubresse, B. Oliva, Z. Misulovin, D. M. Rothstein, G. A. Ellestad, Y. Gluzman, F. P. Tally, I. Chopra, Antimicrob. Agents Chemother. 1991, 35, 2306.

[16] W. Hu, J. Metselaar, L.-H. Ben, P. D. Cravens, M. P. Singh, E. M. Frohman, T. N. Eagar, M. K. Racke, B. C. Kieseier, O. Stuve, PLoS ONE 2009, 4, e4151.

[17] X. F. Liang, H. Tian, H. Luo, H. J. Wang, J. Chang, J. Biomater Sci., Polym. Ed. 2009, 20, 115.

[18] A. Harada, K. Kataoka, Macromol. Symp. 2001, 172, 1.

[19] H. Dautzenberg, C. Konak, T. Reschel, A. Zintchenko, K. Ulbrich, Macromol. Biosci. 2003, 3, 425.

[20] M. Talelli, S. Pispas, Macromol. Biosci. 2008, 8, 960.

[21] C.-H. Wang, W.-T. Wang, G.-H. Hsiue, Biomaterials 2009, 30, 3352.

[22] N. Nishiyama, K. Kataoka, Pharmacol. Ther. 2006, 112, 630.

[23] V. Torchilin, Eur. J. Pharm. Biopharm. 2009, 71, 431.

[24] X.-B. Xiong, H. Uludag, A. Lavasanifar, Biomaterials 2009, 30 , 242.

[25] W. D. Jang, Y. Nakagishi, N. Nishiyama, S. Kawauchi, Y. Morimoto, M. Kikuchi, K. Kataoka, J. Controlled Release 2006, 113, 73.

[26] K. Osada, R. J. Christie, K. Kataoka, J. R. Soc. Interface 2009, 6, S325.

[27] J. M. Wessels, W. E. Ford, W. Szymczak, S. Schneider, J. Phys. Chem. B 1998, 102, 9323.

[28] G. Berthon, M. Brion, L. Lambs, J. Inorg. Biochem. 1983, 19, 1.

[29] WO 2006078925 2006, Warner Chilcott Company, invs.: T. Devries, R. Boissonneault, B. Muldoon, Chem. Abstr. 2006, 736100.
[30] V. Orti, M. Audran, P. Gibert, G. Bougard, F. Bressolle, J. Chromatogr. B 2000, 738, 357.

[31] O. S. Hernandez, G. M. Soliman, F. M. Winnik, Polymer 2007, 48, 921.

[32] G. M. Soliman, F. M. Winnik, Int. J. Pharm. 2008, 356, 248.

[33] H. Walderhaug, O. Söderman, Curr. Opin. Colloid Interface Sci. 2009, 14, 171.

[34] M. J. Nilges, W. S. Enochs, H. M. Swartz, J. Org. Chem. 1991, 56, 5623.

[35] M. Ricci, S. Giovagnoli, P. Blasi, A. Schoubben, L. Perioli, C. Rossi, Int. J. Pharm. 2006, 311, 172.

[36] M. C. Lecaroz, M. J. Blanco-Prieto, M. A. Campanero, H. Salman, C. Gamazo, Antimicrob. Agents Chemother. 2007, 51, 1185.

[37] H. Nelis, A. P. Deleenheer, Drug Metab. Dispos. 1982, 10, 142.

[38] Z. S. Ma, A. Haddadi, O. Molavi, A. Lavasanifar, R. Lai, J. Samuel, J. Biomed. Mater. Res., Part A 2008, 86, 300.

[39] W. H. Bowles, T. J. Bokmeyer, J. Esthet. Restor. Dent. 1997, $9,30$.

[40] H. M. Aliabadi, A. Lavasanifar, Expert Opin. Drug Delivery 2006, 3, 139.

[41] A. Kelarakis, V. Castelletto, M. J. Krysmann, V. Havredaki, K. Viras, I. W. Hamley, Biomacromolecules 2008, 9, 1366.

[42] P. Martinez-Landeira, J. M. Ruso, G. Prieto, F. Sarmiento, M. N. Jones, Langmuir 2002, 18, 3300.

[43] Y. Kakizawa, A. Harada, K. Kataoka, Biomacromolecules 2001, 2, 491.

[44] J. Liu, F. Zeng, C. Allen, J. Controlled Release 2005, 103, 481.

[45] C. De Vocht, A. Ranquin, R. Willaert, J. A. Van Ginderachter, T. Vanhaecke, V. Rogiers, W. Versées, P. Van Gelder, J. Steyaert, J. Controlled Release 2009, 137, 246.

[46] D. E. Owens, N. A. Peppas, Int. J. Pharm. 2006, 307, 93.

[47] Y. Nakamura, O. S. Si, K. Kataoka, Neurosci. Res. 1999, 35 , 95.

[48] R. J. Horvath, N. Nutile-McMenemy, M. S. Alkaitis, J. A. Deleo, J. Neurochem. 2008, 107, 557.

[49] S. S. Kim, P. J. Kong, B. S. Kim, D. H. Sheen, S. Y. Nam, W. Chun, Arch. Pharm. Res. 2004, 27, 314. 